\title{
Correlation Between Traumatic Skin and Subcutaneous Injuries and the Severity of Polytrauma Injury
}

\section{Korrelation von traumatischen Läsionen der Cutis und Subcutis mit der Schwere der Polytraumaverletzung}

Authors

Anna Klempka ${ }^{1,2}$, Christian Fischer ${ }^{3}$, Hans-Ulrich Kauczor ${ }^{1}$, Marc-André Weber ${ }^{1}, 4$

Affiliations

1 Department of Diagnostic and Interventional Radiology, Heidelberg University Hospital, Heidelberg, Germany

2 Institute for Radiology, Neuroradiology and Nuclear Medicine, Klinikum Darmstadt, Darmstadt, Germany

3 Centre for Orthopedics, Trauma Surgery and Spinal Cord Injury, HTRG - Heidelberg Trauma Research Group, Heidelberg University Hospital, Heidelberg, Germany

4 Department of Diagnostic and Interventional Radiology, Pediatric Radiology and Neuroradiology, Rostock University Medical Centre, Rostock, Germany

Key words

abdominal wall, thorax, thorax wall, head injury

received 15.08 .2019

accepted 16.06.2020

published online 26.11 .2020

Bibliography

Fortschr Röntgenstr 2021; 193: 177-185

DOI 10.1055/a-1207-0797

ISSN 1438-9029

(c) 2020. Thieme. All rights reserved.

Georg Thieme Verlag KG, Rüdigerstraße 14,

70469 Stuttgart, Germany

Correspondence

Anna Klempka

Klinikum Darmstadt - Department of Diagnostic Radiology, Neuroradiology and Nucklear Medicin, Grafenstraße 9, 64283 Darmstadt, Darmstadt Hessen 64283, Germany

Tel.: ++ 49/6151/1076751

Fax: ++49/6151/1076849

ann.klempka@gmail.com

\section{ZUSAMMENFASSUNG}

Ziel Korrelationsbestimmung zwischen kutanen und subkutanen Läsionen wie Prellung, Hämatom, Schürfwunde, Hautemphysem mit inneren posttraumatischen Verletzungen zur Evaluierung des klinischen Entscheidungsprozesses bei der Indikationsstellung zur Polytrauma-Ganzkörper-CT.

Methoden und Materialien 250 Patienten, die PolytraumaGanzkörper-CTs erhielten, wurden nach Genehmigung dieser
Studie seitens der Ethikkommission retrospektiv evaluiert. Die CTs wurden durchgeführt, sofern die Patienten die Kriterien für die entsprechende SOP an unserer Institution erfüllten. CTs des Neurokraniums, Hals, Thorax und Abdomens, inkl. Becken und proximalen Oberschenkeln sowie mindestens eine kontrastmittelgestützte Phase enthaltend, wurden in die Studie einbezogen. Die erste Analyse der CTs wurde unmittelbar nach der Durchführung von einem radiologischen Oberarzt sowie einem Assistenzarzt vorgenommen. Bei der ersten Prüfung standen die sofort zu therapierenden inneren Verletzungen im Vordergrund. Die zweite Analyse im Hinblick auf eine detaillierte Analyse der Hautoberfläche wurde separat von einem fachärztlichen Radiologen durchgeführt. Alle Hautläsionen wurden in einer Tabelle festgehalten, die sowohl das betroffene Körperteil als auch den Grad der Verletzung zeigt.

Ergebnisse Eine oberflächliche Läsion der Thoraxwand wurde bei 19 Patienten festgestellt, von denen 17 eine innere Thoraxverletzung hatten. Nur 2 Patienten mit einem Thoraxwandhämatom wiesen keine innere Verletzung auf. Kutane und subkutane Läsionen der Thoraxwand traten am häufigsten auf in Verbindung mit inneren Verletzungen. Hautläsionen der Abdominalwand wurden bei 30 Patienten beobachtet. Nur in 11 Fällen waren diese Läsionen mit inneren Verletzungen verbunden, wie zum Beispiel Frakturen oder aktiven Blutungen. 52 kutane, subkutane und subgaleale Läsionen des Schädels wurden beobachtet. Bei 20 dieser Patienten wurde eine intrakranielle oder innere Verletzung festgestellt. Bei 3 Patienten gab es Hautabschürfungen am Hals und nur in einem Fall war dies mit einer inneren Verletzung verbunden.

Schlussfolgerung Bei Patienten, deren Unfallhistorie sowie klinische Situation die Kriterien für die Polytrauma-Ganzkörper-CT SOP erfüllten und bei denen kutane und subkutane Läsionen, insbesondere am Neurokranium oder Thorax, vorlagen, kam es häufiger zu inneren Läsionen.

\section{Kernaussagen:}

- Das Vorhandensein oder Fehlen einer oberflächlichen Verletzung der Abdominalwand ist kein verlässlicher Vorhersagefaktor für eine innere Bauchverletzung.

- Wenn eine oberflächliche Verletzung der Brust oder des Neurokraniums feststellbar wäre, sollte ein CT-Scan durchgeführt werden.

- Oberflächliche Verletzungen der Thoraxwand waren am stärksten mit inneren Verletzungen assoziiert. 


\section{ABSTRACT}

Purpose To examine the relationship between superficial lesions (such as bruises, hematomas, deep abrasions, and soft tissue emphysema) and internal post-traumatic injuries, assessed using whole-body computed tomography (WBCT), and to determine if these are valid markers for internal injuries.

Methods and Materials 250 patients who underwent WBCT emergency scans for suspected polytrauma were retrospectively analyzed after institutional review board approval of the study. The scans were carried out on patients who met the criteria for standard operating procedures for WBCT emergency scans. WBCT covering the entire head, neck, chest, and abdomen (including pelvis and proximal lower extremities) and at least one phase with intravenous contrast agent were included in the study. Initial analyses of immediate WBCT scans was carried out by a consultant radiologist and a radiological resident. The first reading focused on internal damage that needed immediate therapy. The second reading focused on a detailed analysis of the skin and subcutaneous tissue and their relation to internal injuries without the time pressure of an emergency setting, carried out by another experienced radiologist. All skin lesions and the degree of penetration and a comparison between the two readings were reported in tables.

Results Superficial lesion of the chest was detected in 19 patients, 17 of them had an internal injury of the thorax while only two patients, with hematoma of the chest wall, had no internal injuries. Skin and subcutaneous lesions of the chest had the strongest association with an internal injury. Skin lesions of the abdominal wall were observed in 30 patients. In only 11 cases, these lesions were correlated with internal injuries, such as fractures or active bleeding. 52 skin and subgaleal lesions of the scalp were observed. In 20 of these patients, an intracranial or internal injury was detected. In 3 patients, skin abrasions of the neck were present and in only one of them, this finding was associated with an internal injury.

Conclusion Trauma patients whose history and clinical presentation meet the standard operating procedures for WBCT emergency scans and who present with a cutaneous lesion, especially at the neurocranium or chest wall, should be observed for internal injuries by WBCT.

\section{Key Points:}

- Presence or lack of a superficial injury of the abdominal wall is not a reliable predictive indication of any internal abdominal injury.

- Superficial lesions of the chest and the neurocranium require a CT scan.

- Superficial injuries of the chest wall had the strongest association with internal injuries.

\section{Citation Format}

- Klempka A, Fischer C, Kauczor H et al. Correlation Between Traumatic Skin and Subcutaneous Injuries and the Severity of Trauma. Fortschr Röntgenstr 2021; 193: 177-185

\section{Introduction}

Currently, whole-body computed tomography (WBCT) is the fastest and the most frequently used method for cross-sectional imaging of polytraumatized injured patients. However, patient triage presents a challenge to medical personnel applying WBCT in their clinical practice. The detection of potential internal injury vs. radiation exposure of the often young patients must be taken into consideration in the clinical judgement [1].

In Germany, WBCT is currently recommended for polytraumatized patients according to the Association of the Scientific Medical Societies [2]. However, there is a large group of polytrauma patients that fulfills some criteria of suspected major trauma due to history of trauma but presents no severe clinical symptoms to qualify them for WBCT.

There is obviously a crucial need to tailor diagnostic imaging to the specific needs of patients involved in traumatic accidents. Our study investigated the skin body surface and subsurface area of patients undergoing WBCT. The body surface area (BSA) of human skin varies depending on body weight from $1.97 \pm 0.143$ to $3.07 \pm 0.225 \mathrm{~m}^{2}$ [3]. This large area of accessible skin provides a unique opportunity for the easy detection of superficial post-traumatic lesions, which could be linked to more severe internal injuries. It is recognized that only serious skin injuries will be detected on a CT scan.
The aim of this study is to investigate whether the detection of a bruise, hematoma, foreign body or trapped air on WBCT was correlated with internal injuries and could become a valid diagnostic sign thus facilitating rapid detection of internal injuries. As a consequence of selective detection, cross imaging approaches could be possible, which would rapidly reduce radiation exposure of young adults after trauma. Our hypothesis was that superficial injuries at specific locations correlate with internal injuries on the WBCT emergency scan.

\section{Materials and Methods}

After Institutional Review Board approval, a retrospective analysis of 250 consecutive cases of post-traumatic patients was performed. The inclusion criteria involved all patients ( $>18$ years old) admitted to our university hospital during a consecutive 6-month period with whole-body emergency scan (WBCT scan was performed including the head, neck, thoracic and abdominal cavities and at least one phase with intravenous contrast agent was injected). An emergency team consisting of two surgeons with experience in emergency medicine, an experienced anesthesiologist and an experienced radiologist evaluated the inclusion criteria to perform posttraumatic cross-sectional imaging with WBCT. A decision about performing cross-sectional imaging was 
made after analyzing the vital signs, performing clinical examination, taking history of trauma and performing Focused Assessment with Sonography for Trauma (FAST) ultrasonographic examination. The FAST examination was performed to rule out and detect free fluid collections (interpreted as potentially active bleeding or acute hematoma) in the left and right upper abdominal quadrants, as well as the pericardial cavity or in the pouch of Douglas.

In summary, the criteria leading to a WBCT scan were as follows:

- Abnormalities in vital signs.

- Relevant history of trauma, such as the affection of more than two injured body regions on physical examination, high-speed accidents or falls of more than one meter.

- Relevant findings in the FAST examination, such as free fluid collection or signs of any damage to internal organs.

Analysis of the cases revealed that the majority of traumas (62\%, $\mathrm{n}=156$ ) were caused by traffic incidents, such as automobile collisions ( $n=81$ ), two-wheeled vehicle accidents (including motorbikes and bicycles) $(n=68)$, and accidents involving pedestrians $(n=7)$. Falls from more than one meter were reported in 54 cases ( $22 \%$ ). The cause of trauma in 22 patients ( $9 \%$ ) was not established. Other traumatic incidents occurred in 18 patients (7\%) and included uncommon accidents that could not be classified into one of the groups listed above, such as domestic violence or being struck by lightning.

Superficial injuries detectable with WBCT were the following ( $\triangleright$ Table 1):

- Contusion/superficial bruise - a subcutaneous tissue injury with an intact skin surface. Clinically, within a few hours after trauma, a gradually developing bruise is observed. A bruise presents as blurred opacity of approximately 25-55 Hounsfield Units (HU), causing light hyperdensity in the subcutaneous tissue on CT ( $\vee$ Table $1 \mathrm{~A})$.

- Deep bruise - a contusion of subcutaneous tissue with a simultaneous disruption and injury of the skin surface. On CT scan, a blurred opacity of approximately 25-55 HU and visible disruption of skin surface can be detected ( $\vee$ Table 1B).

- Hematoma - a localized collection of blood in the muscular tissue, presented as hyperdensity or inhomogeneity on CT without contrast agent. Hematoma shows density of approximately 25-60 HU without contrast agent and may cause a mass effect, especially through arterial bleeding ( $\triangleright$ Table 1C).

- Foreign body - a foreign object under the skin surface such as metallic structures, as well as stones or grains of sand are easily detected on CT as sharp well-defined structures penetrating the body surface. Many non-contrast-enhanced foreign bodies such as thick wood or glass splinters are visible due to their mass size and abnormal geometric structure in comparison to the anatomical structures. The density varies between -50 and $3500 \mathrm{HU}$ ( $\vee$ Table 1D).

- Subcutaneous emphysema - a collection of trapped gas in the layer beneath the skin or muscle. On CT scans, there is a subcutaneous opacity approximately of minus 200-1000 HU ( $\triangleright$ Table 1E).
Our targeted areas were as follows: the head including facial skeleton and neurocranium, the neck, the thorax including shoulders, the abdomen, the pelvis and proximal thigh. The extremities in full-length were not included in this study. In general, the extremities are sufficiently assessed during clinical examination and cross-sectional imaging should be only used at most on an individualized case-by-case basis (e. g. no distal pulse). It should be noted that patients with subgaleal hematoma were also included in this study. A subgaleal hematoma arises in the space between the periosteum and galea aponeurosis, and it is not considered to be of a subcutaneous nature. The variety of shapes, from circular to irregular, precluded an exact estimation of the extent, severity and volume of all lesions.

\section{Second reading}

The second retrospective reading of WBCT with special appreciation of skin lesions was recorded by an experienced radiologist and was without time pressure. However, it should be noted that the second reader was not blinded to the results of the first reading. The comparison between the internal injuries in the first and second readings was estimated $>$ Table 6 .

\section{Patients}

The patients in our study consisted of 163 men and 87 women ( $50 \pm 21.7$ years). Based on their history of trauma, there was no statistically significant difference in the type of trauma with regard to gender.

\section{WBCT}

$\mathrm{CT}$ images were acquired using a 128-row CT scanner. Patients received a tube voltage (k)V ranging between 80-140 kV. Sharp bony and soft-tissue kernels were used for image reconstruction and immediate coronal and sagittal images were generated. The first WBCT reading was always performed by a consultant radiologist and a radiology resident, and a consensus was reached as to whether internal damage was present or not. The second round of CT reading was performed by another experienced radiologist with special attention given to skin or subcutaneous lesions.

\section{Statistics}

Statistical analyses tested whether the observed skin injuries were related to a certain body area or a specific type of accident. Statistical analyses were carried out using $R$ software (version 3.3.2). Chi-squared tests were used to test for correlations between the measured variables

Detailed correlations between the following parameters were calculated:

If a skin/subcutaneous injury as well as subgaleal hematoma was associated with intracranial bleeding/fracture or contusion of the head.

If a skin/subcutaneous injury, especially including subcutaneous emphysema, was associated with an internal contusion of the thoracic cavity.

If a skin/subcutaneous injury was especially associated with a fracture or hematoma of the neck. 
- Table 1 Various skin lesions and their appearance on CT scans.

- Tab.1 Verschiedene Hautläsionen und deren Erscheinungsbild in CT-Scans.

\begin{tabular}{|c|c|c|}
\hline type of skin lesion & imaging finding on CT scan & description \\
\hline A. contusion & . & $\begin{array}{l}\text { Subsurface tissue injured skin surface remained intact. (Clinically, within a } \\
\text { few hours after trauma there will be a sign of bruise that develops gradually.) }\end{array}$ \\
\hline B. deep bruise & & Contusion of the subcutaneous tissue and the skin surface with disruption. \\
\hline C. hematoma & & $\begin{array}{l}\text { Localized collection of blood in muscular tissue is visible without any contrast } \\
\text { agent, due to increased volume of the organ and ongoing growth at differ- } \\
\text { ent scan phases, when active bleeding is present. }\end{array}$ \\
\hline D. foreign body & & $\begin{array}{l}\text { An unwanted intruded object located under the skin surface. } \\
\text { As an example, a small stone is visible after a motocross collision at the level } \\
\text { of left frontal bone. }\end{array}$ \\
\hline E. subcutaneous & & A collection of trapped gas in a layer under a muscle. \\
\hline
\end{tabular}


- Table 2 Correlation between superficial injuries of the neurocranium (including subgaleal hematoma) and an internal injury.

- Tab.2 Korrelation zwischen einer oberflächlichen Schädigung des Neurokraniums (einschließlich eines subgalealen Hämatoms) und einer inneren Schädigung.

\begin{tabular}{|c|c|c|c|c|c|}
\hline \multirow[t]{2}{*}{ WBCT } & \multicolumn{2}{|c|}{$\begin{array}{l}\text { superficial injury } \\
(n=52)\end{array}$} & \multicolumn{2}{|c|}{$\begin{array}{l}\text { no superficial injury } \\
(n=198)\end{array}$} & \multirow[t]{2}{*}{$\begin{array}{l}\text { P-value } \\
\text { (Chi-squared test) }\end{array}$} \\
\hline & $\mathbf{n}$ & $\%$ & $\mathbf{n}$ & $\%$ & \\
\hline internal injury of neurocranium & 20 & 38.5 & 13 & 6.6 & \multirow[t]{2}{*}{$<0.001$} \\
\hline no internal injury of neurocranium & 32 & 61.5 & 185 & 93.4 & \\
\hline
\end{tabular}

If a skin/subcutaneous injury including bruise and hematoma was associated with injury of the abdominal cavity/or pelvis.

For each correlation, a separate significance level was obtained, in addition to positive predictive (PPV) and negative predictive values (NPV) corrected for multiple testing.

The trauma history was correlated with potential skin and subcutaneous damage of the head, neck, viscerocranium, thoracic cavity and abdominal cavity including the pelvis, and was reported separately. For this analysis, Fisher's exact tests were used.

Comparison between the internal injuries from the first and second readings was estimated using McNemar's test.

\section{Results}

\section{Neurocranium}

A superficial injury of the neurocranium was observed in 52 patients. 20 of them had a fracture or intracranial bleeding. An internal injury of the neurocranium was significantly more common in patients with skin injury ( $p<0.05$, Chi-squared test) yielding a positive predictive value of $38 \%$ and a negative predictive value of $93 \%$ ( $\triangleright$ Table 2, $\triangleright$ Fig. 1). Superficial injuries of the neurocranium were typically associated with a fall, uncommon accidents, which were three times more common than traffic accidents $(p<0.05)$ or traumas due to unknown causes.

\section{Viscerocranium}

A superficial injury of the viscerocranium was observed in 26 patients. 12 of these had a deeper injury of the facial skeleton. The correlation was statistically significant $(p<0.05)(\triangleright$ Table 3 , - Fig. 2). Superficial injuries of the facial skeleton were usually related to the history of an unknown traumatic cause.

\section{Neck}

There were three patients with a superficial injury of the cervical area and no statistically significant $(p>0.05)$ results were observed.

\section{Thoracic cavity}

A superficial injury to the thoracic cavity was observed in 19 patients. 17 of them had a fractured rib or lung injury. There was

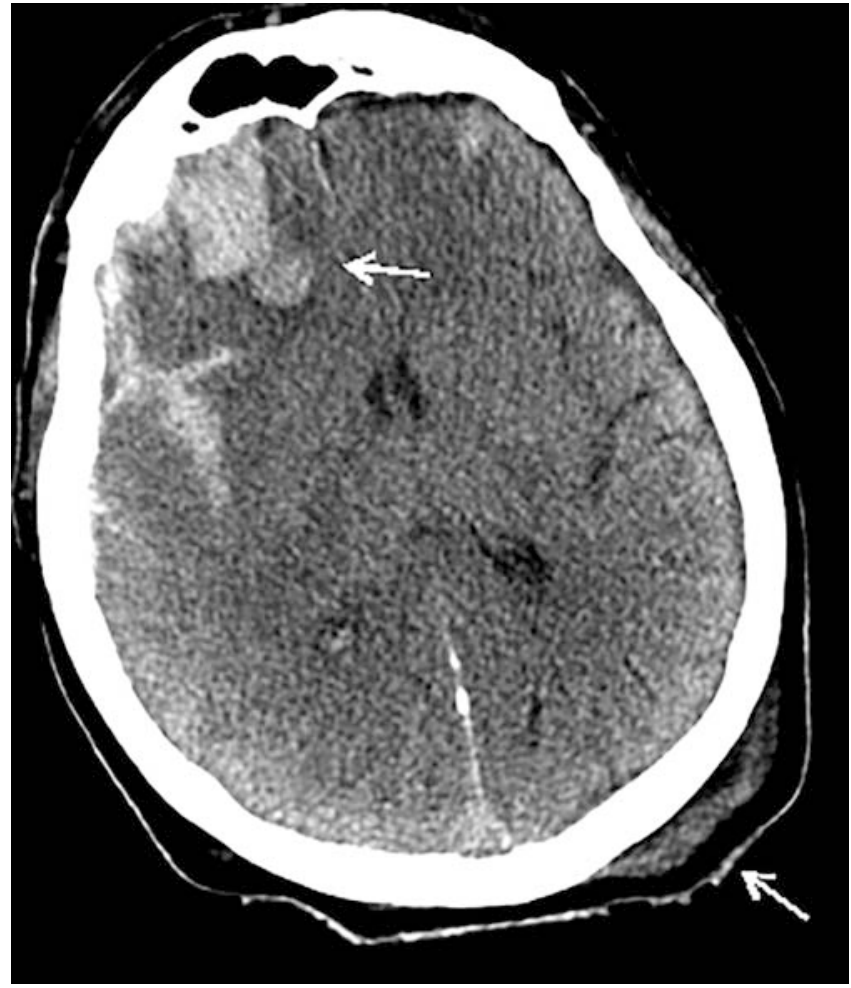

- Fig. 1 An example of injury of the neurocranium. A 22-year-old man after a traffic accident. There is contre-coup injury by frontal intracranial intraparenchymal and subarachnoidal bleeding (arrow) as well as a subgaleal hematoma (coup injury) on the contralateral occipital side (arrow).

- Abb. 1 Ein Beispiel für eine Verletzung des Neurokraniums. Ein 22-jähriger Mann nach einem Verkehrsunfall. Es liegt eine Contrecoup-Verletzung mit frontalen intrakraniellen intraparenchymalen und subarachnoidalen Blutungen (Pfeil) sowie ein subgaleales Hämatom auf der kontralateralen Occipitalseite (Pfeil) vor.

a statistically significant correlation $(p<0.001)$, ( $\triangleright$ Table 4, - Fig. 3). The PPV was nearly $89.5 \%$, whereas the NPP was $74 \%$. There was no significant correlation between the type of superficial injury and specific type of accident. 
- Table 3 Correlation between the superficial injuries of the viscerocranium and an internal injury.

- Tab.3 Korrelation zwischen der oberflächlichen Verletzung von Viszerokranium und einer inneren Verletzung.

\begin{tabular}{|l|l|l|l|l|}
\hline WBCT & $\begin{array}{l}\text { superficial injury } \\
\text { (n= 26) }\end{array}$ & \% & $\begin{array}{l}\text { no superficial injury } \\
\text { (n=224) }\end{array}$ & $\begin{array}{l}\text { p-value } \\
\text { (Chi-squared test) }\end{array}$ \\
\hline & $\mathbf{n}$ & $\mathbf{n}$ & $\%$ \\
\hline internal injury of viscerocranium & 12 & 46.2 & 1 & 0.5 \\
\hline no internal injury of viscerocranium & 14 & 53.9 & 223 & 99.6 \\
\hline
\end{tabular}

- Table 4 Correlation between superficial injuries of the thoracic cavity and an internal injury.

- Tab.4 Korrelation zwischen der oberflächlichen Verletzung der Brusthöhle und einer inneren Verletzung.

\begin{tabular}{|c|c|c|c|c|c|}
\hline \multirow[t]{2}{*}{ WBCT } & \multicolumn{2}{|c|}{$\begin{array}{l}\text { superficial injury } \\
(n=19)\end{array}$} & \multicolumn{2}{|c|}{$\begin{array}{l}\text { no superficial injury } \\
(n=231)\end{array}$} & \multirow[t]{2}{*}{$\begin{array}{l}\text { p-value } \\
\text { (Chi-squared test }\end{array}$} \\
\hline & n & $\%$ & $\mathbf{n}$ & $\%$ & \\
\hline internal injury of thorax & 17 & 89.5 & 60 & 25.8 & \multirow[t]{2}{*}{$<0.001$} \\
\hline no internal injury of thorax & 2 & 11.8 & 171 & 74.0 & \\
\hline
\end{tabular}

\section{Abdominal cavity}

A superficial injury of the abdominal wall was observed in 30 patients. 11 of them had a fracture or internal injury. There was no statistically significant correlation $(p>0.05)$ between internal injuries and superficial lesions. The PPV was $36.7 \%$ ( $>$ Table 5, $\triangleright$ Fig. 4).

\section{Second reading ( $\vee$ Table 6 )}

Comparison between the internal injuries from the first and second readings. The second reading showed statistical significance in the thoracic region (McNemar's test $=0.0004$ ). No vitally relevant injuries were recognized during the second reading that have been overlooked at the first reading.

\section{Summary of the results}

- Superficial injuries of the skull and thorax on WBCT most likely correlate with internal injury.

- No statistical correlation was observed between abdominal or cervical trauma and superficial injuries detected on the WBCT scans.

- Traumatic events, such as a fall, traumas of unknown etiology, and other accidents associated with skin lesions were most likely associated with internal injuries.

\section{Discussion}

Patients with relevant traumatic incidents present an inhomogeneous group of individuals with different levels of clinical severity. The value of prioritizing WBCT for severely injured patients remains

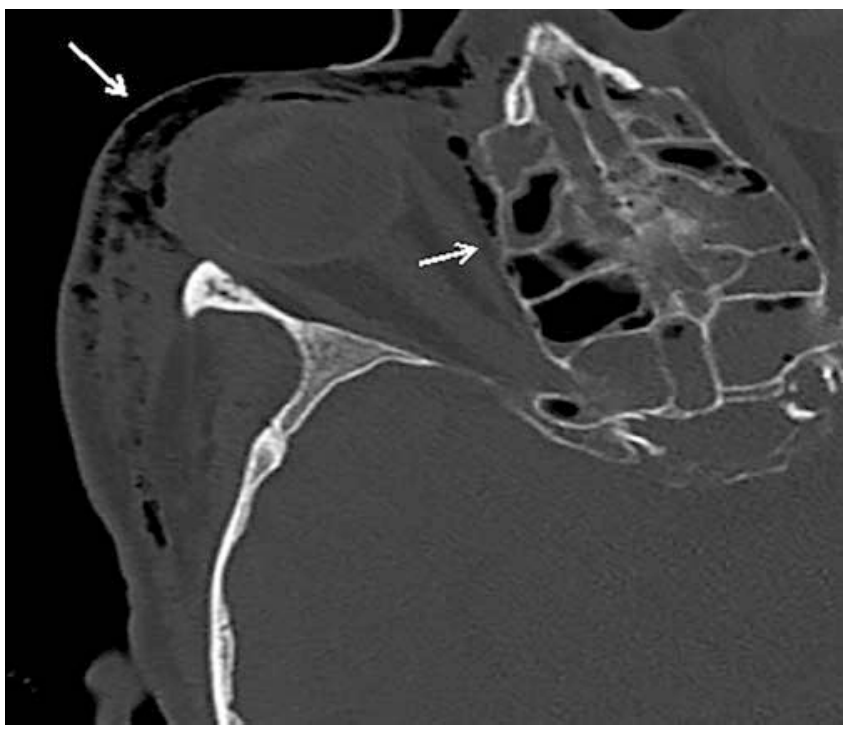

- Fig. 2 An example of injury of the viscerocranium. 40-year-old woman with some subcutaneous emphysema (arrow) due to communicating trauma (arrow) of a nasal cavity and subcutis after bicycle accident.

- Abb. 2 Ein Beispiel für eine Verletzung des Viszerokraniums. 40-jährige Frau nach einem Fahrradunfall mit subkutanem Emphysem (Pfeil) aufgrund einer kommunizierenden Verletzung (Pfeil) der Nasenhöhle und der Subkutis.

incontestable [5, 6]. Determining which injured patients with varying degrees of severity will undergo WBCT is nowadays one of the 


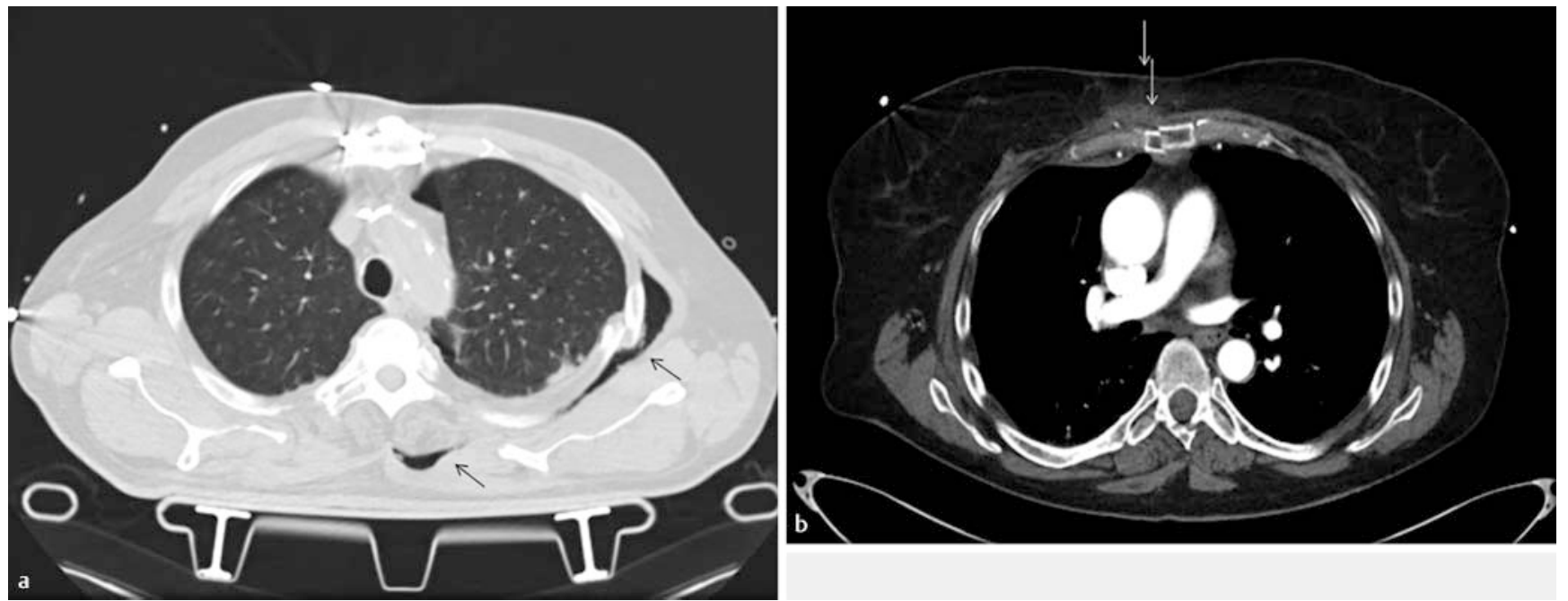

Fig. 3 a A 53-year-old man presenting with a pneumothorax on the left side and mild lung contusion due to a rib fracture after a car accident. Air trapping in soft tissues (arrows) is also present. b A 52-year-old man with a sternum fracture (arrows) and mediastinal hematoma after a car collision. It is necessary to rule out cardiac trauma and pericardial effusion as well as pneumothorax, aortic dissection, and lung contusion.

- Abb. 3 a Ein Beispiel für Verletzungen in der Brusthöhle. Ein 53-jähriger Mann nach einem Autounfall, der sich mit einem Pneumothorax auf der linken Seite und einer leichten Lungenkontusion sowie einer Rippenfraktur vorgestellt hat. Ein Hautemphysem ist hier ebenfalls sichtbar und in den Weichteilen eingeschlossen (Pfeile). b Ein Beispiel für Verletzungen in der Brusthöhle. Ein 52-jähriger Mann nach einem Autounfall mit einer Brustbeinfraktur (Pfeile) und einem mediastinalen Hämatom. Ein Herztrauma und ein Perikarderguss sowie ein Pneumothorax, eine Aortendissektion und eine Lungenkontusion müssen ausgeschlossen werden.

- Table 5 Correlation between superficial injury of the abdominal cavity and an internal injury.

- Tab.5 Korrelation zwischen einer oberflächlichen Verletzung der Bauchhöhle und einer inneren Verletzung.

\begin{tabular}{|c|c|c|c|c|c|}
\hline \multirow[t]{2}{*}{ WBCT } & \multicolumn{2}{|c|}{$\begin{array}{l}\text { superficial injury } \\
(n=30)\end{array}$} & \multicolumn{2}{|c|}{$\begin{array}{l}\text { no superficial injury } \\
(\mathrm{n}=220)\end{array}$} & \multirow[t]{2}{*}{$\begin{array}{l}\text { P-value } \\
\text { (Chi-squared test) }\end{array}$} \\
\hline & n & $\%$ & $\mathbf{n}$ & $\%$ & \\
\hline internal injury of abdomen & 11 & 36.7 & 48 & 21.8 & \multirow[t]{2}{*}{$=0.117$} \\
\hline no internal injury of abdomen & 19 & 63.3 & 172 & 78.2 & \\
\hline
\end{tabular}

most important decisions made by trauma teams [7, 8]. Our study examined the use of visually accessible lesions that can be detected during simple clinical examination as potential markers for specific severe internal traumas revealed by WBCT.

Our results show that superficial injury of the thoracic wall is a valuable factor for potential internal damage, which has been confirmed by other authors [7]. CT scanning of the thoracic cavity allows exact visualization of treatable traumas and as a consequence makes it possible to quickly manage them. Our study verified that chest wall traumas warrant performing WBCT as they are highly correlated with internal damage and have a positive predictive value of $89 \%$. Previously, Collins et al. reported that severe chest wall trauma can be associated with large chest wall hematomas or free air within the chest wall. This type of injury could lead to surgical procedures and should be recognized and reported as soon as possible [9-11]. The study from Lang et al. shows that the routine use of WBCT for thoracic traumas increases the identification of so-called minor thoracic injuries [12].

Our study substantiates the importance of scalp trauma with any subgaleal hematoma. The positive predictive value of $38 \%$ and negative of $93 \%$ point out the statistical dependence. Furthermore, our observation has advantage over some clinical papers that investigated some of the related clinical scales. For example, according to the Glasgow Coma Scale, the neurological symptoms of the patient showed no evidence for a predictive value for intracranial lesions [13].

Another study pointed out a black eye as a possible sign of an underlying fracture in patients with a minor head injury [14]. Viscerocranium injuries are often identified by a selective workup. In our study they showed some statistical significance since the positive predictive value was $46 \%$.

The second WBCT reading discovered some missed injuries without clinical significance for the injured patients. The findings 
- Table 6 Comparison between the first and second reading due to internal damage. The second reading showed statistical importance in the thoracic region [4].

- Tab.6 Vergleich zwischen der ersten und zweiten Befundung hinsichtlich interner Schäden. Die zweite Befundung ergab eine statistische Differenz in der Brustregion [4].

\begin{tabular}{|l|l|l|l|}
\hline body part & $\begin{array}{l}\text { internal injuries } \\
\text { by first reading }\end{array}$ & internal injuries by second reading & McNemar's test \\
\hline neurocranium & 23 & $\begin{array}{l}27 \text { (two skull fractures, not significant by all other intracranial injuries: } \\
\text { additional subarachnoid and subdural bleeding was found) }\end{array}$ & 0.134 \\
\hline vicerocranium & 13 & 17 (three small not relevant fractures, one hematosinus) & 0.134 \\
\hline neck & 3 & 4 (one small muscular hematoma) & 1 \\
\hline thoracic cavity & 77 & $\begin{array}{l}87 \text { (five not dislocated rib fractures, four fractures of the lateral process } \\
\text { of the vertebral body, one small lung contusion) }\end{array}$ & 0.004 \\
\hline abdomen & 59 & $\begin{array}{l}61 \text { (one small subcapsular renal bleed, one not dislocated vertebral } \\
\text { body fracture) }\end{array}$ & 0.248 \\
\hline
\end{tabular}

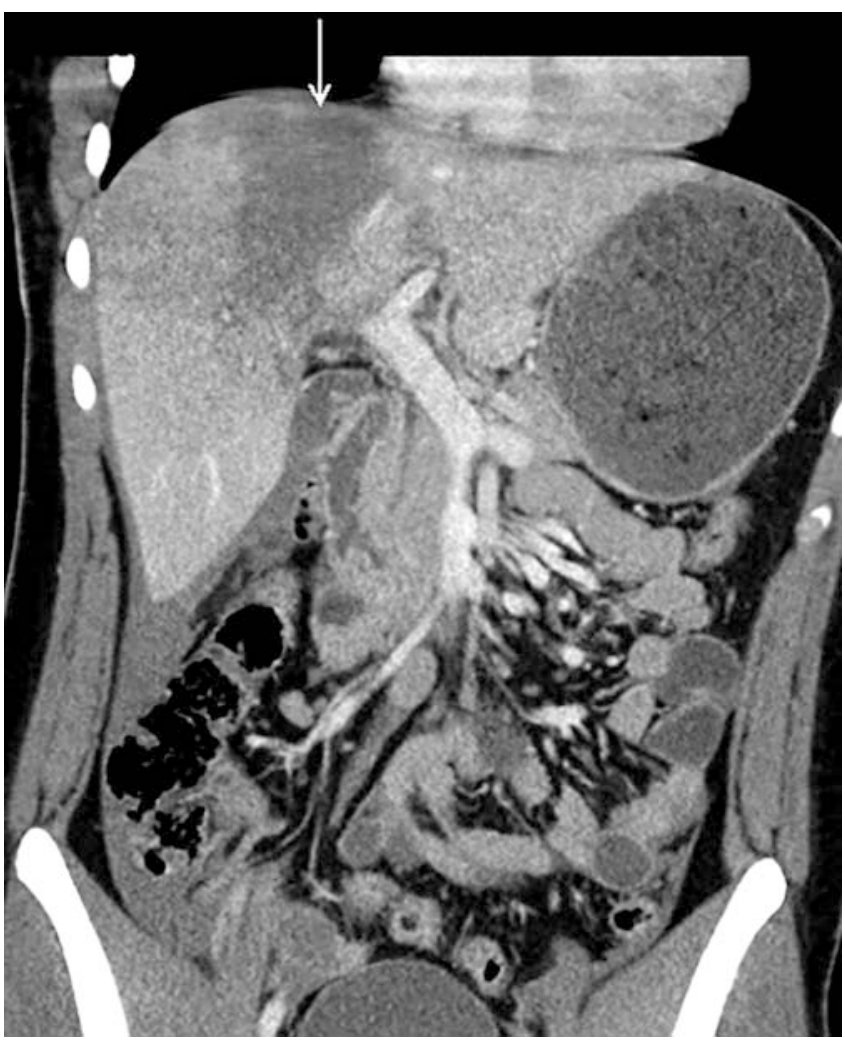

- Fig. 4 A 50-year-old man after a fall from a height as an example of an injury within the abdominal cavity with parenchymal disruption (arrow) involving approximately $40 \%$ of the right lobe resulting in a grade IV AAST liver injury.

- Abb.4 Ein 50-jähriger Mann nach einem Sturz aus großer Höhe als Beispiel für eine Verletzung in der Bauchhöhle mit Parenchymzerstörung (Pfeil), von der ungefähr $40 \%$ des rechten Leberlappens betroffen sind, was zu einer AAST-Leberschädigung Grad IV entspricht. in the chest area showed some statistical significance, therefore strengthening our thesis that superficial injuries can strongly correlate with further internal injuries. The second WBCT reading should be taken into consideration to lower potential miscounted injuries and allow for the precise management of injured patients.

The assumption that all body areas would be accessible for clinical examination to the same extent as for cross-sectional imaging in polytraumatic patients was one of the limitations of our study. Certain body areas may not be accessible for clinical examination in an emergency setting, for example due to spine-stabilizing equipment. The second limitation of our study was related to the fact that our retrospective observation of the superficial lesions on CT scans was not correlated with a clinical examination. The third limitation was that data were obtained only from one university hospital center. Thus, our observations should be confirmed by multi-centric studies on larger populations.

Despite these limitations, our study opens up a new perspective regarding the field of polytrauma imaging with its variety of injuries from a real-world clinical setting. Existing studies typically focus on specific types of injuries in selected groups of patients (e. g. minor head traumas) and have consequently improved general knowledge. Yet, in the daily clinical routine, most patients suffer from multiple traumas, requiring a comprehensive and integrated approach. Therefore, our study included not just patients with isolated injuries.

Another research group [15] postulated that regular monitoring of WBCT findings paired with regular feedback from clinical examination would help to select patients with positive internal trauma for WBCT selection. In addition, the workflow in cases of life-threatening situations as well as the optimization of scan parameters in trauma management needs to be addressed [16]. There are many researchers who show no benefits of WBCT versus selective radiological workup [17-19] as well as those who point out many benefits of immediate cross-sectional imaging [20, 21]. There are other studies that suggest a selected approach [22]. 
A discussion about indication and justification of WBCT connects the clinical and radiological workup. The commonly recommended feedback regarding WBCT findings by the radiologist to the clinician indicates great potential regarding close interdisciplinary cooperation in emergency medicine. Some authors highlight that evaluation and awareness of the clinical status is superior to the traumatic history in order to properly determine an indication for WBCT examinations [23].

In conclusion, we would like to raise awareness that traumatic lesions of the skin and subcutaneous tissue should not be underestimated in cross-sectional imaging reports as well as the clinical examination. Superficial lesions may justify the indication for WBCT and, as demonstrated by our study, when a superficial lesion occurs on the chest or neurocranium, an internal injury should be considered and furthermore selective cross-sectional imaging should be performed when clinically reasonable. Our findings should increase the detection of patients profiting from WBCT and help to avoid some underestimation of clinical information provided to the radiologist in their radiological reports.

\section{Conflict of Interest}

The authors declare that they have no conflict of interest.

\section{References}

[1] Brenner D], Elliston CD. Estimated radiation risks potentially associated with full-body CT screening. Radiology 2004; 232: 735-708

[2] S3-Leitlinie Polytrauma/Schwerverletzten-Behandlung. AWMF Register Nr. 012/019. http://www.awmf.org/leitlinien/detail/ll/012-019.html

[3] Livingston EH, Lee S. Body surface area prediction in normal-weight and obese patients. Am J Physiol Endocrinol Metab 2001; 281: E586-E591

[4] R Core Team (2019). A language and environment for statistical computing. R Foundation for Statistical Computing, Vienna, Austria. URL https://www.R-project.org/

[5] Zotzmann V, Rilinger J, Lang CN et al. Early full-body computed tomography in patients after extracorporeal cardiopulmonary resuscitation (eCPR). Resuscitation 2019. doi:10.1016/j.resuscitation.2019.11.024

[6] Hueber-Wagner S, Lefering R, Quick LM et al. Effect of whole-body CT during trauma resuscitation on survival: a retrospective, multicentre study. Lancet 2009; 25373: 1455-1461

[7] Belabbas D, Auger M, Lederlin M et al. Whole-Body CT after Motor Vehicle Crash: No Benefit after High-Energy Impact and with Normal Physical Examination. Radiology 2019; 292: 94-100. doi:10.1148/ radiol.2019182806. Epub 2019 May 28

[8] Treskes K, Saltzherr TP, Luitse JS et al. Indications for total-body computed tomography in blunt trauma patients: a systematic review. Eur J Trauma Emerg Surg 2017; 43: 35-42. doi:10.1007/s00068-016-0711-4. Epub 2016 Jul 19
[9] Collins J. Chest wall trauma. J Thorac Imaging 2000; 15: 112-119

[10] Liu J, Yue W, Du D. Multi-slice computed tomography for diagnosis of combined thoracoabdominal injury. Chin J Traumatol 2015; 18: 27-32

[11] Trupka A, Waydhas C, Hallfeldt KK et al. Value of thoracic computed tomography in the first assessment of severely injured patients with blunt chest trauma: results of a prospective study. J Trauma 1997; 43: 405411; discussion 411-412

[12] Lang P, Kulla M, Kerwagen F et al. TraumaRegister DGU. The role of whole-body computed tomography in the diagnosis of thoracic injuries in severely injured patients - a retrospective multi-centre study based on the trauma registry of the German trauma society (TraumaRegister DGU®). Scand J Trauma Resusc Emerg Med 2017; 25: 82

[13] Becker A, Peleg K, Olsha O et al. Israeli Trauma Group, Analysis of incidence of traumatic brain injury in blunt trauma patients with Glasgow Coma Scale of 12 or less. Chin J Traumatol 2018; 16: S10081275(17)30312-7

[14] Büttner M, Schlittler FL, Michel C et al. Is a black eye a useful sign of facial fractures in patients with minor head injuries? A retrospective analysis in a level I trauma center over 10 years. Br J Oral Maxillofac Surg 2014; 52 : 518-522

[15] Shannon L, Peachy T, Skipper E et al. Comparison of clinically suspected injuries with injuries detected at whole-body $\mathrm{CT}$ in suspected multitrauma victims. Clin Radiol 2015; 70: 1205-1211

[16] Gunn ML, Kool DR, Lehnert BE. Improving Outcomes in the Patient with Polytrauma: A Review of the Role of Whole-Body Computed Tomography. Radiol Clin North Am 2015; 53: 639-656

[17] Long B, April MD, Summers $S$ et al. Whole body CT versus selective radiological imaging strategy in trauma: an evidence-based clinical review. Am J Emerg Med 2017; 35: 1356-1362

[18] Sierink KC, Treskes K, Edwards MJR et al. Immediate total-body CT scanning versus conventional imaging and selective $C T$ scanning in patients with severe trauma (REACT-2): a randomized controlled trial. Lancet 2016; 388: 673-683

[19] Palm HG, Kulla M, Wettberg M et al. TraumaRegistrer DGU ${ }^{\circledR}$. Changes in trauma management following the implementation of the whole-body computed tomography: a retrospective multi-centre study based on the trauma registry of the German Trauma Society (TraumaRegister DGU ${ }^{\circledR}$ ). Eur J Trauma Emerg Surg 2018; 44: 759-766

[20] Wurmb TE, Quaisser C, Balling $\mathrm{H}$ et al. Whole body multislice computed tomography (MSCT) improves trauma care in patients requiring surgery after multiple trauma. Emerg Med J 2011; 28: 300-304

[21] Libing J, Yuefeng M, Shouyin J et al. Comparison of whole body computed tomography vs selective radiological imaging on outcomes in major trauma patients: a metaanalysis. Scan J Trauma Resusc Emerg Med 2014; 22: 54

[22] Jingshan G, Dongdong M, Minjie Y et al. Emergency CT of blunt abdominal trauma: experience from a large urban hospital in Southern China. Quant Imaging Med Surg 2017; 7: 461-468

[23] Arora R, Arora A. Justification of whole-body CT in polytrauma patients, can clinical examination help selecting patients? Quant Imaging Med Sur 2019; 9: 636-641 